\title{
Razvoj metoda imunohistokemijskog bojenja i optimizacija protokola za detekciju transkripcijskog faktora BACH2
}

1 Nikolina Vukoja

2 Suzana Hančić

3 Petra Korać

1 Odjel za kliničko-laboratorijsku dijagnostiku, Dječja bolnica Srebrnjak, Srebrnjak 100, Zagreb, Hrvatska

2 Klinički zavod za patologiju i citologiju, KB Merkur, Zajčeva 19, Zagreb, Hrvatska

3 Zavod za molekularnu biologiju, Biološki odsjek, Prirodoslovno-matematički fakultet Sveučilišta u Zagrebu, Horvatovac 102A, Zagreb, Hrvatska

\section{Sažetak}

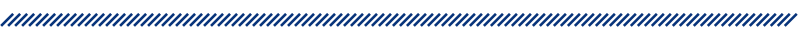

Imunohistokemijsko bojenje jest metoda detekcije prisutnosti i lokalizacije specifičnih antigena u stanici ili tkivu. Primjenjuje osnovni princip imunosne reakcije kod kojeg se specifično antitijelo veže na određeni antigen koji prepoznaje. Razvoj imunohistokemijskih metoda započeo je 1930-ih godina, od kada se, sve do danas, primjenjuju u različitim oblicima za mnoga znanstvena istraživanja i u rutinskim dijagnostičkim postupcima.

$\mathrm{U}$ ovom radu opisan je razvoj metoda imunohistokemijskog bojenja te je prikazana optimizacija protokola za detekciju antigena BACH2 u ljudskom sekundarnom limfnom tkivu. Raspravljeni su pojedini koraci metode poput pripreme prereza tkiva koje se analizira, uvjeti demaskiranja antigena i inkubacije specifičnim antitijelom te je predložen optimalan protokol bojenja za naveden antigen primjenjiv $u$ rutinskom hematopatološkom laboratoriju.

Ključne riječi: imunohistokemijsko bojenje, BACH2, demaskiranje epitopa, inkubacija antitijelom

Datum primitka: 01.05.2017.

Datum prihvaćanja: 15.10.2017.

DOI: $10.24141 / 1 / 3 / 2 / 9$

Adresa za dopisivanje:

Petra Korać

E-pošta: petra.korac@biol.pmf.hr

Tel.: +38514606278

Zavod za molekularnu biologiju, Biološki odsjek, Prirodoslovno-matematički fakultet, Horvatovac 102A, Zagreb, Hrvatska 


\section{Uvod}

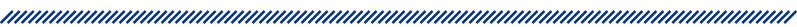

Imunohistokemijsko bojenje jest metoda za detekciju prisutnosti i lokalizacije antigena u rezovima tkiva s pomoću specifičnih antitijela, odnosno seta reagensa koji omogućavaju vizualizaciju reakcije antigen/antitijelo. Principi imunohistokemijskog bojenja poznati su od 1930-ih godina prošlog stoljeća, ali tek je 1941. godine objavljen prvi prikaz ove metode. Kratki pregled najvažnijih koraka koji su pridonijeli razvoju metoda imunohistokemijskog bojenja prikazan je u tablici 1. Princip nastajanja antitijela kod kralježnjaka osnova je svih imunoenzimatskih metoda koje se primjenjuju u laboratorijskoj dijagnostici.

\subsection{Princip imunohistokemijske metode}

Metoda imunohistokemijskog bojenja kakvu danas poznajemo osmišljena je 1940. godine, a rutinski se upotrebljava i danas kao važan korak u dijagnostici' Imunohistokemijsko bojenje nezaobilazna je metoda i u znanstveno-istraživačkom radu. Postoji mnogo različitih načina vizualizacije ciljanih stanica u tkivima primjenom imunohistokemijskog bojenja ili drugih metoda temeljenih na tom postupku. Ipak, primjena svakog novog antitijela specifičnog za pojedini antigen često treba pažljivu optimizaciju, ovisno o tkivu ili svojstvima ciljanih proteina, vezanih molekula i/ili načina vizualizacije reakcije².

Klasičan postupak imunohistokemijskog bojenja prikazan je na slici 1. Uključuje detekciju epitopa (dijela antigena koji antitijelo prepoznaje) u uzorku tkiva primjenom primarnog antitijela koje može vezati epitope s visokom specifičnošću. Nakon vezanja epitopa i primarnog antitijela dodaje se sekundarno antitijelo koje može vezati primarno antitijelo također s visokom specifičnošću. Na sekundarno antitijelo vezana je molekula za detekciju, koja nakon stvaranja kompleksa primarno antitijelo/sekundarno antitijelo omogućava vizualizaciju istraživanog epitopa, tj. antigena ${ }^{3}$.

U shematskom prikazu na slici 1 upotrijebljeno je tkivo koje je fiksirano u formalinu i uklopljeno u parafin. Nakon otkrivanja antigena tretirano je primarnim antitijelom specifičnim za proteinski antigen CD20. Otopina određenog razrjeđenja primarnog antitijela dodana je na tkivni prerez te je inkubacija trajala tijekom vremena potrebnog da dođe do maksimalnog vezanja molekula antigena i antitijela. Nakon ovog koraka isprana su nevezana antitijela i dodano je sekundarno antitijelo. Sekundarno antitijelo, koje je povezano s peroksidazom hrena
(HRP, od engleskog horseradish peroxidase), naneseno je na uzorak te se tijekom iduće inkubacije sekundarno antitijelo vezalo za primarno. Nakon inkubacije sekundarnim antitijelom uzorak se ponovno isprao da se uklone nevezana antitijela. Vizualizacija je učinjena 3,3' diaminobenzidinom (DAB). Enzim HRP pretvorio je supstrat DAB-a u smeđi precipitat koji se stvara u tkivu na mjestu reakcije te tako vizualizira mjesto vezanja primarnoga specifičnog antitijela i ciljanog antigena (u ovom slučaju membranskog proteina CD20 specifičnog za B-limfocite). Ovakav način vizualizacije, koji uključuje sekundarno antitijelo koje nosi enzim potreban za vizualizaciju specifične reakcije, najčešće je korištena varijanta metode u rutinskim dijagnostičkim laboratorijima.

\subsection{Priprema uzorka}

Tkivo koje se istražuje ima ključnu ulogu u uspješnosti metode pa je od iznimne važnosti da je obrađeno na način kojim su očuvani epitopi antigena i odgovarajuća morfologija samog tkiva. Uobičajena obrada tkiva za imunohistokemiju jest fiksiranje u neutralnom formalinu te uklapanje u parafin. Svrha je fiksacije formalinom stvaranje kemijski potaknutih križnih veza proteina u tkivu. Taj postupak zaustavlja sve stanične procese i zadržava stanične komponente u mjestu i u obliku u kojem su bili za vrijeme fiksacije te sprječava propadanje komponenti stanice. Nakon odgovarajuće fiksacije, tkivo se dalje obrađuje da bi se moglo prožeti tekućim parafinom i pohraniti u obliku parafinskih blokova, koji se nakon toga mogu rezati u tanke rezove ( 1 do $5 \mu \mathrm{m}$ ) na mikrotomu. Tanki se rezovi potom prenose na adhezivna predmetna stakla na kojima su učvršćeni za daljnju obradu².

Osim uporabe formalina, nekada su korištene i druge metode fiksacije, najčešće postupcima koji uključuju razne vrste aldehida ili otopine alkohola. Vrlo su česta alternativa tkivima fiksiranima formalinom i uklopljenima u parafin smrznuti svježi uzorci tkiva. U tom je slučaju tkivo uklopljeno u krioprotektivni medij i zamrznuto, a fiksacija se učini nakon što je tkivo izrezano i postavljeno na predmetno staklo. Smrznuta tkiva režu se u kriostatu i imaju prednost kratke obrade i bolje očuvanih osjetljivih epitopa, ali vrlo često mogu biti manje informativna u odnosu na tkiva fiksirana formalinom i uklopljena u parafin, zbog manje očuvane morfologije tkiva ${ }^{4}$.

\subsection{Otkrivanje epitopa antigena}

Maskiranje epitopa antigena najveći je izazov koji nastaje fiksiranjem tkiva - događa se zbog križnih vezanja u fiksativu kao što je formalin ili predugom vremenu u 


\begin{tabular}{|c|c|c|}
\hline GODINA & METODA & REFERENCIJE \\
\hline 1941. & Primjena primarnih antitijela označenih fluorokromom & Coons i suradnici ${ }^{1}$ \\
\hline 1967. & Primjena primarnih antitijela označenih enzimom & Nakane i Pierce ${ }^{23}$ \\
\hline 1970. & Primjena sekundarnih neoznačenih antitijela (metoda peroksidaza-antiperoksidaza) & Sternberger i suradnici ${ }^{24}$ \\
\hline 1970. & Detekcija antigena na vrlo tankim rezovima & Kawarai i Nakane 25 \\
\hline 1974. & $\begin{array}{l}\text { Primjena imunohistokemijskog bojenja u rutinskim dijagnostičkim postupcima } \\
\text { upotrebom rezova fiksiranih formalinom i uklopljenih u parafin }\end{array}$ & Taylor i suradnici $\mathrm{i}^{26,27,28}$ \\
\hline 1975. & Razvoj monoklonalnih antitijela & Koehler i Milstein 29 \\
\hline 1978. & $\begin{array}{l}\text { Razvoj metode dvostrukog bojenja primjenom neoznačenih antitijela (metoda } \\
\text { alkalna fosfataza - antialkalna fosfataza) }\end{array}$ & Mason i Sammons ${ }^{30}$ \\
\hline 1979. & Primjena monoklonalnih antitijela za detekciju ljudskih antigena & McMichael i suradnicisi \\
\hline 1988. & Primjena kapilarnog uspona za razvoj metode poluautomatskog bojenja & Brigati i suradnici ${ }^{32}$ \\
\hline 1991. & Primjena otkrivanja antigena s pomoću topline & Shi i suradnici33 \\
\hline 1993. & Standardizacija postupka & Taylor ${ }^{34}$ \\
\hline 1995. & Primjena dekstranskog polimera za detekciju & Dako $^{3}$ \\
\hline 1998. & Primjena imunohistokemijskog bojenja kao standardne metode u dijagnostici & Dako $^{3}$ \\
\hline 2007. & Preporuke za bolju standardizaciju imunohistokemijskih metoda & $\begin{array}{l}\text { Goldstein i suradnici }{ }^{35} \\
\text { Wolff i suradnici }{ }^{36}\end{array}$ \\
\hline 2008. & Razvoj testova za detekciju amplifikacije HER2 u imunohistokemijskim laboratorijima & Allison ${ }^{37}$ \\
\hline
\end{tabular}

kojem je tkivo izloženo fiksativu. Maskiranje epitopa sprječava vezanje primarnog antitijela i specifičnog antigena. Potreba za otkrivanjem epitopa prije daljnjih koraka u imunohistokemiji posebno je prisutna kod tkiva fiksiranih formalinom i uklopljenih u parafin. Postoji nekoliko dostupnih protokola otkrivanja antigena, a glavne strategije uključuju tretiranje tkiva na predmetnom stakalcu toplinom, digestivnim enzimima, deterdžentima ili kombinacijom svega navedenog. Najčešća je metoda otkrivanja antigena na tkivu fiksiranim formalinom i uklopljenim u parafin tretiranje stakala s tkivom puferima različitih $\mathrm{pH}$-vrijednosti pod visokim tlakom i na visokoj temperaturi u periodu od 15 do 20 minuta 5 .

\subsection{Vezanje antitijela}

Kvaliteta, specifičnost i klonalnost antitijela presudna je za bilo koju imunohistokemijsku metodu te je njegov izbor ključan za kvalitetu, pouzdanost i interpretaciju rezultata. lako je većinom komercijalno dostupnih antitijela moguće precizno detektirati željeni antigen, ponekad su moguće vrlo velike varijacije u njihovoj specifičnosti. Antitijela s visokom specifičnošću učinkovitija su kod interpretacije ciljanog vezanja, jer proizvode vrlo malo nespecifičnih vezanja ili ih uopće ne stvaraju, koja uzrokuju nastanak pozadinskog bojenja. Antitijela sa slabijom specifičnošću učestalije se nespecifično vežu te se stvara pozadinsko bojenje koje ometa interpretaciju pravih signala ${ }^{6}$. Postoje dvije osnovne vrste antitijela: poliklonalna antitijela koja su mješavine antitijela specifičnih za različite epitope istog antigena i monoklonalna antitijela koja sva vežu isti epitop nekog antigena. Poliklonalna antitijela često su vrlo uspješna kod detekcije antigena prisutnog i u vrlo malim količinama zbog svoje sposobnosti detektiranja i vezanja raznih epitopa istog proteina. Ipak, epitopi koje vežu takva antitijela često nisu vrlo specifični za pojedini antigen pa dolazi do povećane mogućnosti vezanja nespecifičnih molekula i stvaranja pozadinskog bojenja koje ometa interpretaciju. Nedostatak je upotrebe poliklonalnih antitijela, osim pozadinskog bojenja, njihova ograničena količina, jer se izoliraju iz seruma životinja u kojima su napravljena ${ }^{7}$. Monoklonalna antitijela moguće je proizvesti u velikim količinama jer se proizvode kao stanične linije iz hibridoma stanica koje su nastale fuzijom limfocita iz slezene imunizirane životinje s tumorskim stanicama mijeloma i najčešće su visokospecifična za određeni epitop. I monoklonalna antitijela mogu stvarati nepouzdane rezultate koje je teško interpretirati ako nisu visokospecifična i ako je ciljani epitop prisutan u malim količinama ${ }^{8}$. 
Svako antitijelo zahtijeva detaljnu optimizaciju za bilo koju vrstu imunohistokemijskih metoda na temelju titracije koncentracije antitijela za svako specifično tkivo jer je rezultat ovisan o specifičnosti antitijela i afinitetu prema antigenu, kao i o količini i dostupnosti specifičnih i potencijalnih nespecifičnih epitopa koji su prisutni u uzorku .

\subsection{Mehanizam vizualizacije reakcije antigena i antitijela}

Imunohistokemijsko bojenje primjenjuje se za određivanje vrste stanica u tkivu koje se istražuje, određivanje ekspresije istog antigena u svim stanicama tkiva ili u nekoj od prisutnih populacija, kao i za određivanje lokalizacije proteina koji se istražuje. Za postizanje vidljivosti interakcije između antitijela i ciljanog antigena potreban je sustav detekcije koji stvara vidljivo obojenje ili signal. Najčešće je korištena metoda uvođenje sekundarnog antitijela koje nosi reportersku molekulu, primjerice enzim ili fluorofor. Sekundarna antitijela gotovo uvijek reagiraju s molekulama antitijela napravljenima u različitim životinjskim vrstama. Na primjer, ako je primarno antitijelo izolirano iz zeca, onda sekundarno antitijelo mora biti izolirano iz druge životinjske vrste i specifično isključivo za zečja antitijela9 .

Za detekciju antigena prisutnih u tkivima fiksiranima formalinom i uklopljenima u parafin najčešća je metoda detekcije enzimska reakcija koja stvara obojeni precipitat na mjestu vezanja antitijela. Sekundarno antitijelo koje nosi enzim, primjerice peroksidazu hrena (HRP) ili alkalnu fosfatazu (AP, od engleskog alkaline phosphatase), oksidira kromogene poput 3,3' diaminobenzidina (DAB) ili 5-bromo-4-kloro-3-indolil fosfata / p-nitroblue tetrazolium klorida (BCIP/NBT) od kojih stvara smeđe ili plave precipitate koji nastaju u tkivu na mjestu reakcije. Kromogena obojenja vidljiva su pod svjetlosnim mikroskopom i obično su vrlo stabilna kroz dugo razdoblje, što je prednost ako uzorci moraju biti pohranjeni ili pregledani nakon nekog vremena ${ }^{10}$.

Za smrznuta se tkiva češće upotrebljavaju antitijela na koja su vezani fluorofori koji emitiraju svjetlost specifične valne duljine (obično zelenu ili crvenu) kada su podraženi određenim spektrom svjetlosti. Fluorofori nisu stabilni kroz duže razdoblje. Prednost je upotrebe fluorofora što omogućavaju dvostruko označavanje, tj. simultana primjena dvaju antitijela specifičnih za različite antigene $u$ istom dijelu stanice. Sekundarna antitijela tada moraju biti specifična za različita primarna antitijela (iz različitih životinja) i označena različitim fluoroforima ${ }^{11}$.
Primjena sekundarnih antitijela za detekciju sama je po sebi korak umnažanja signala jer nekoliko sekundarnih antitijela može vezati jedno primarno antitijelo, a nekada je dodatno umnažanje i potrebno da bi se povećao signal i osjetljivost analize. U takvom slučaju sekundarno antitijelo može nositi vezane molekule, primjerice polimere biotina koji mogu preusmjeriti veći broj reporterskih molekula u daljnjim koracima. Ova je strategija umnažanja signala korisna i za enzimatske i fluorescencijske mehanizme detekcije ${ }^{3}$.

\subsection{Kontrastiranje tkivnih prereza}

Primjena kontrastnih boja kod imunohistokemijskih metoda pojačava razliku pozitivnih i negativnih imunohistokemijskih reakcija i olakšava prepoznavanje histoloških struktura, kao i signala koji nastaje tim bojenjem. Najčešći je tip kontrastiranja za tkiva fiksirana formalinom i uklopljena u parafin bojenje hematoksilinom koji staničnu citoplazmu boji svjetloplavom bojom, a staničnu jezgru tamnije plavim nijansama. Kod fluorescencijskih je metoda uobičajeno kontrastiranje kromatina dodatkom fluorescentne boje DAPI (od engleskog 4,6-diamidino-2-phenylindole). Nakon koraka vizualizacije i kontrastiranja, imunohistokemijsko bojenje završava stavljanjem pokrovnog stakalca na tkivo koje se nalazi na predmetnom staklu uz primjenu sredstva za poklapanje koje izravnava površinu preparata ${ }^{12}$.

\subsection{Različite vrste imunohistokemijskog bojenja}

Vizualizacija imunohistokemijske reakcije može se odvijati na nekoliko načina. Ovisno o tome je li primarno antitijelo direktno obilježeno vizualizacijskim sredstvom, imunohistokemijske metode možemo podijeliti u direktne i indirektne. Direktna metoda bojenja u jednom koraku temelji se na specifičnom antitijelu koje je obilježeno fluorescentnom bojom, npr. fluorescein izotiocijanatom (FITC) ili rodaminom koji na mjestu vezanja emitiraju svjetlo određene valne duljine. Ovaj pristup upotrebljava samo jedno antitijelo, što cijeli postupak čini kratkim. Metoda nije jako osjetljiva zbog nedovoljnog umnažanja signala i rijetko se primjenjuje ${ }^{13}$. Indirektna metoda uključuje neoznačeno specifično primarno antitijelo (prvi sloj) koje reagira s tkivnim antigenom i bojom ili enzimom označeno sekundarno antitijelo (drugi sloj) koje reagira s primarnim antitijelom. Ova je metoda osjetljivija zbog umnažanja signala zbog velikog broja reakcija sekundarnog antitijela s različitim epitopima primarnog antitijela. Metoda je ekonomična jer se ista sekundarna antitijela mogu upotrebljavati s mno- 
go specifičnih primarnih antitijela nastalih u istoj životinjskoj vrsti. Sekundarna antitijela mogu biti označena fluorokromom te se to naziva indirektnom fluorescentnom metodom. Isto tako, mogu biti označena enzimom poput peroksidaze hrena, alkalne fosfataze i glukozne oksidaze. Tada je riječ o indirektnoj imunoenzimskoj metodi ${ }^{14}$. Indirektne metode dalje se razlikuju s obzirom na način vizualizacije i pojačavanja specifičnog signala.

Metoda peroksidaze i antiperoksidaze (metoda PAP, od engleskog Peroxidase-Antiperoxidase Method) jest metoda koja uključuje treći sloj reagensa u reakciju vezivanja. Treći je sloj zečje antitijelo za peroksidazu upotrebljava se da bi se stvorio vrlo stabilan kompleks peroksidaze i antiperoksidaze. Kompleks koji se sastoji od zečjeg gama-globulina i peroksidaze služi kao treći sloj koji se veže na nekonjugirani drugi sloj, kozji antizečji gama-globulin. Osjetljivost je 100 do 1000 puta veća od temeljne metode zbog toga što molekula peroksidaze nije kemijski konjugirana anti-IgG-om, već je vezana imunosnom reakcijom pa ne gubi enzimatsku aktivnost. Ova metoda omogućava primjenu većeg razrjeđenja primarnog antitijela i reducira nespecifično pozadinsko bojenje ${ }^{15}$.

Metoda kompleksa avidina i biotina ( $A B C$, od engleskog Avidin-Biotin Complex) osjetljivija je od metode PAP. Avidin, veliki glikoprotein, može biti označen peroksidazom ili fluorokromom, a ima veliki afinitet za biotin. Biotin, vitamin male molekularne težine, može biti vezan s različitim molekulama, poput antitijela. Ova tehnika uključuje tri sloja - prvi je sloj neoznačeno primarno antitijelo, drugi je sloj biotinizirano sekundarno antitijelo, a treći je sloj kompleks avidin-biotinske peroksidaze. Nakon toga, peroksidaza se detektira s pomoću DAB-a ili nekog drugog supstrata da bi se stvorili završni kolorimetrijski proizvodi ${ }^{16}$.

Metoda označavanja streptavidinom i biotinom (LSAB, od engleskog Labeled Streptavidin-Biotin Complex) upotrebljava streptavidin izoliran iz bakterije Streptococcus Avidini, kao zamjenu za avidin. Molekula streptavidina jest nenabijena, za razliku od avidina koji ima izoelektričnu točku 10 , stoga je elektrostatičko vezanje za tkivo uklonjeno. Uz to, streptavidin ne sadrži grupe ugljikohidrata, koje se mogu vezati za lektine u tkivu i tako stvarati pozadinsko bojenje. Metoda LSAB tehnički je vrlo slična standardnoj metodi $A B C$. Prvi je sloj neoznačeno primarno antitijelo, drugi je sloj biotinizirano sekundarno antitijelo, a treći je sloj konjugat enzima i streptavidina (HRP-strepavidin ili AP-streptavidin) koji zamjenjuje kompleks avidin-biotinske peroksidaze. Bojenje završava dodavanjem otopine supstrata kromogena kako bi se stvorio precipitat vidljiv svjetlosnim mikroskopom.
Treći sloj može biti i fluorokrom-streptavidin kao što je FITC-streptavidin, u slučaju da je potrebno fluorescentno označavanje. Metoda LSAB jest pet do deset puta osjetljivija od standardne metode $A B C^{17}$.

Metoda EnVision (od engleskog EnVision Systems) temelji se na tehnologiji polimera dekstrana. Dekstran je okosnica na koju je vezano oko 10 sekundarnih antitijela i oko 70 enzimskih molekula (peroksidaze hrena ili alkalne fosfataze). Time je pojačana osjetljivost te smanjeno nespecifično pozadinsko bojenje. Također, reduciran je ukupni broj koraka u samom testu u usporedbi s već poznatim metodama. Protokol je jednostavan, uključuje primjenu primarnog antitijela, enzimskog polimera i kromogena ${ }^{18}$.

Metoda ImmPRESS (od engleskog ImmPRESS polymerized reporter enzyme staining system) kao osnovu primjenjuje polimeriziranje enzima i dodavanje tih polimera antitijelima. Njezin je napredak formiranje enzimskih mikropolimera koji će izbjeći intrinzične nedostatke primjene velikih dekstrana ili drugih makromolekula kao okosnice. Dodavanje jedinstvenog mikropolimera vrlo aktivnih enzima na sekundardno antitijelo stvara reagens koji je, za razliku od polimera u metodi EnVision, niske molekularne težine i lakše prodire u tkivo. Rezultat je izvrsna osjetljivost, vidljivost signala, smanjeno pozadinsko bojenje i reducirano nespecifično vezanje. Protokol uključuje primjenu primarnog antitijela, enzimskih polimera i kromogena ${ }^{19}$.

\subsection{Transkripcijski faktor $B A C H 2$}

U rutinskoj se praksi imunohistokemijske metode najčešće primjenjuju u području patologije kako bi se lakše prepoznale i odredile tkivne strukture. Kod znanstvenih istraživanja, poput istraživanja u području hematopatologije, imunohistokemijsko bojenje najčešće se primjenjuje za analizu stanica koje eksprimiraju neki specifični protein kako bi se odredila njegova prisutnost ili količina u stanici ili tkivu.

Velik broj alergija i autoimunih bolesti, kao što su Crohnova bolest, astma, dijabetes 1. tipa i multipla skleroza, povezani su s polimorfizmom gena koji kodira transkripcijski faktor $\mathrm{BACH} 2^{20}$. Da bi pravilno funkcionirao, imunosni se sustav oslanja na osjetljivu ravnotežu između stanica koje potiču imunosnu reakciju i onih koje je reguliraju. Kada stanice koje potiču imunosnu reakciju postanu neadekvatno aktivne ili stanice koje je reguliraju postanu neučinkovite, dolazi do autoimunog oboljenja ${ }^{21}$.

$\mathrm{BACH} 2$ je regulator aktivacije imunosne reakcije koji uravnotežuje aktivnost regulatornih imunosupresivnih stanica (Treg) i istovremeno ograničava diferencijaciju 
mnogostrukih upalnih CD4+ T-stanica. Zbog važne uloge u regulaciji aktivacije imunosnog sustava, $\mathrm{BACH} 2 \mathrm{je}$ interesantna meta za razvoj novih načina liječenja autoimunih, alergijskih i tumorskih oboljenja. Važan je i za razvoj novih načina liječenja tumora jer tumorska tkiva reakcijama s regulatornim T-stanicama često zavaravaju imunosni sustav i tako se zaštite od uništenja ${ }^{22}$.

$\mathrm{U}$ ovom radu opisana je optimizacija protokola imunohistokemijskog bojenja antigena BACH2 u tkivu fiksiranom formalinom i uklopljenom u parafin primjenom komercijalno dostupnog antitijela.

\section{Materijali i metode}

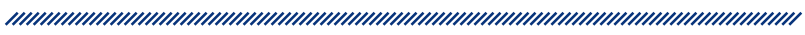

\subsection{Materijali}

Za optimizaciju navedene metode upotrijebljene su tonzile dobivene nakon tonzilektomije koje su fiksirane u formalinu i uklopljene u parafin. Parafinske kocke s tkivom rezane su mikrotomom na tanke rezove debljine $2 \mu \mathrm{m}$. Upotrijebljeni uzorci dio su materijala Kliničkog zavoda za patologiju i citologiju KB-a Merkur u Zagrebu namijenjenog uspostavi protokola imunohistokemijskih bojenja u rutinskoj praksi.

Primarno antitijelo bilo je poliklonalno, proizvedeno u kozi, specifično za protein BACH2 (Santa Cruz Biotechnology, Inc., Dallas, SAD) za koji se očekuje da je eksprimiran u B-limfocitima germinativnih centara tonzila, ali i u okolnim T-stanicama.

\subsection{Metode}

\subsubsection{Razotkrivanje epitopa antigena}

Razotkrivanje epitopa antigena potaknuto je visokim tlakom i temperaturom, tj. metodom HIER (od engle- skog Heat Induced Epitope Retrieval). Ispitivana su po dva tkivna prereza tonzile kuhanjem u puferskim otopinama kiselosti pH-vrijednosti 6,0, 6,1 i 9,0. Otopine pH-vrijednosti 6,0 i 6,1 citratni su puferi, a otopina pH-vrijednosti 9,0 jest otopina Tris/EDTA. Tretman otopinama niske $\mathrm{pH}$ vrijednosti pri visokom tlaku proveden je u uređaju Pascal (Dako, Danska) na $125^{\circ} \mathrm{C} \mathrm{kroz} \mathrm{dvije} \mathrm{minute,} \mathrm{a} \mathrm{kuhanje}$ u visokoj pH-vrijednosti u uređaju PT Link (Dako, Danska) na $97^{\circ} \mathrm{C}$ kroz dvadeset minuta. Primjenom dvaju osnovnih razrjeđenja odabranog antitijela (1: 100 i $1: 500)$, prema preporuci proizvođača, moguće je odrediti najprikladniji pufer za razotkrivanje epitopa antigena.

\subsubsection{Vrijeme inkubacije i razrjeđenje primarnog antitijela}

Nakon određivanja pufera koji daje najbolji rezultat razotkrivanja epitopa antigena, potrebno je ispitati $u$ kojem su razrjeđenju primarnog antitijela i vremenu inkubacije rezultati imunohistokemijskog bojenja jasni i nedvojbeni. U preparatu ne smije biti pozadinskog bojenja, a u tkivu tonzile stanice germinativnog centra moraju pokazivati jako nuklearno obojenje. Kako bi se dobio jasan signal, testirana su razrjeđenja antitijela $1: 50,1: 75,1: 100$ i $1: 500$ različitih vremena inkubacija - 30, 45, 60 i 75 minuta te inkubacija preko noći na $+4{ }^{\circ} \mathrm{C}$. Sa svakim je ispitivanim uzorkom kao negativna kontrola upotrijebljeno tkivo tonzile kojem je u protokolu izostavljen korak inkubacije primarnim antitijelom.

\subsubsection{Protokol metode imunohistokemijskog bojenja mikropolimerima}

Aparat za automatsko bojenje koji se upotrebljavao pri izvedbi ove metode bio je Autostainer Link 48 (Dako, Danska).

Prvi korak bio je blokiranje endogene peroksidaze s pomoću otopine BLOXALL Blocking Solution (Vector Laboratories, Inc., SAD) kojom se uzorak tkiva na predmetnom staklu tretira 10 minuta. BLOXALL služi za blokiranje

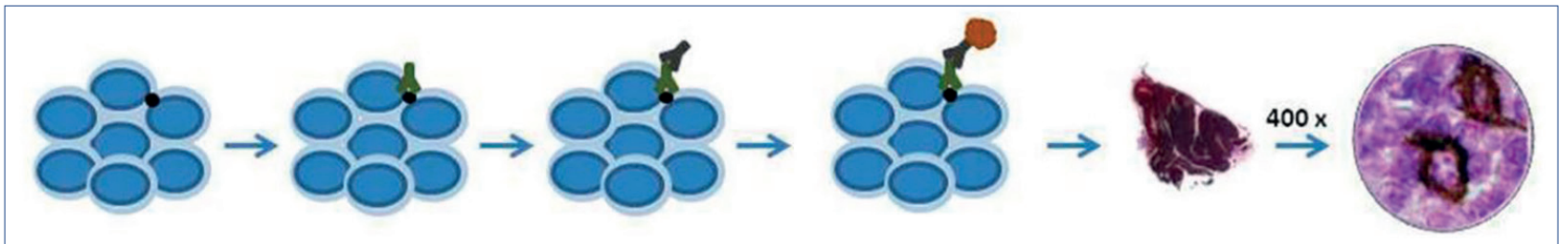

Slika 1. Shematski prikaz postupka i slika mikroskopskog preparata nastalog klasičnim imunohistokemijskim bojenjem. Preparat prikazuje B-limfocite u tkivu tonzile, tj. stanice koje eksprimiraju protein CD20 detektiran smeđim kromogenom. 
aktivnosti endogene peroksidaze i pseudoperoksidaze jer njihova prisutnost u tkivu stvara lažno pozitivan rezultat. Otopina se može upotrebljavati za tkiva fiksirana formalinom uklopljena u parafin. Nakon blokiranja slijedi ispiranje uzorka TBS-puferom (od engleskog Tris Buffered Saline) pH-vrijednosti 7,6 tijekom pet minuta.

Drugi je korak inkubacija preparata u 2,5-postotnom normalnom konjskom serumu tijekom 20 minuta kako bi se spriječilo nespecifično vezanje antitijela.

Treći je korak inkubacija specifičnim primarnim antitijelom. Nakon toga slijedi ispiranje puferom tijekom pet minuta.

Četvrti je korak inkubacija s reagensom ImmPRESS (Vector Laboratories, Inc., SAD) tijekom 30 minuta, čime se postiže vrlo osjetljiv sustav za detekciju i smanjuje pozadinsko bojenje. Mikropolimeri ImmPRESS ograničavaju sterične interferencije i omogućavaju olakšan pristup antitijela ciljanom antigenu. Rezultat je intenzivno bojenje koje stvara čisti signal. Nakon toga slijedi ispiranje puferom dva puta po pet minuta.

Dodavanjem kromogena reakcija antigena i antitijela postaje vidljiva jer kromogen oksidira u prisutnosti peroksidaze. Upotrijebljen je kromogen DAB (FLEX DAB, Dako), kojim je preparat tretiran tijekom 10 minuta.

Završno se stakla ispiru u tekućoj vodi te kontrastiraju hematoksilinom u periodu od pet minuta. Kako bi preparat postao trajan, tkivni se rezovi dehidriraju, prožmu ksilenom te se tkiva poklapaju pokrovnim staklima uz primjenu smola na bazi ksilena.

\section{Rezultati}

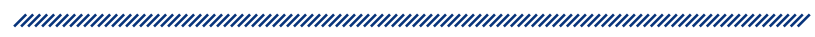

Imunohistokemijsko bojenje prereza tonzile protokolom ImmPRESS uz primjenu pufera za demaskiranje kiselosti pH-vrijednosti 6,0, specifičnog antitijela razrijeđenog $1: 100$ i vremena inkubacije antitijelom u trajanju od 30 minuta nije pokazalo prisutnost antigena. Rezultat je samo plavo obojenje stanica dobiveno kontrastiranjem hematoksilinom, dok ekspresiju proteina $\mathrm{BACH} 2$ nije moguće detektirati (slika 2a).

Imunohistokemijsko bojenje prereza tonzile protokolom ImmPRESS kod kojeg je upotrijebljen pufer za demaskiranje kiselosti $\mathrm{pH}$-vrijednosti 6,0 i razrjeđe- nje specifičnog antitijela $1: 500$ tijekom inkubacije od 30 minuta također nije pokazalo prisutnost antigena. Vidljivo je samo plavo obojenje stanica dobiveno kontrastiranjem hematoksilinom, dok ekspresiju proteina $\mathrm{BACH} 2$ nije moguće detektirati (slika 2b).

Imunohistokemijskim bojenjem prereza tonzile protokolom ImmPRESS kod kojeg je primijenjen pufer za demaskiranje kiselosti pH-vrijednosti 6,1 i specifično antitijelo razrijeđeno $1: 100$ tijekom inkubacije od 30 minuta u pojedinim stanicama germinativnih centara i T-stanicama tonzile pokazuje se signal koji predstavlja ekspresiju antigena BACH2. Nema pozadinskog bojenja, ali je signal imunohistokemijskog bojenja vrlo slab (slika 2c).

Imunohistokemijsko bojenje prereza tonzile s protokolom ImmPRESS kod kojeg je primijenjen pufer za demaskiranje kiselosti pH-vrijednosti 6,1 uz razrjeđenje specifičnog antitijela $1: 500$ i vrijeme inkubacije od 30 minuta daje vidljivo samo plavo obojenje stanica dobiveno kontrastiranjem hematoksilinom, dok ekspresiju proteina $\mathrm{BACH} 2$ nije moguće detektirati. $U$ vrlo rijetkim stanicama slabo se nazire signal koji predstavlja analizirani antigen (slika 2d).

Prerez tonzile imunohistokemijski obojen protokolom ImmPRESS uz primjenu pufera za demaskiranje kiselosti pH-vrijednosti 9,0 i specifičnog antitijela razrjeđenja 1 : 100 tijekom inkubacije od 30 minuta stvara pozadinsko bojenje bez signala specifičnog za analizirani antigen (slika 2e).

Imunohistokemijsko bojenje prereza tonzile protokolom ImmPRESS kod kojeg je primijenjen pufer za demaskiranje kiselosti pH-vrijednosti 9,0 i razrjeđenje specifičnog antitijela 1 : 500 tijekom inkubacije od 30 minuta ne omogućava detekciju ekspresije proteina $\mathrm{BACH}$. Vidljivo je samo plavo obojenje stanica dobiveno kontrastiranjem hematoksilinom, a nema ni pozadinskog bojenja (slika 2f).

Imunohistokemijsko bojenje prereza tonzile protokolom ImmPRESS kod kojeg je primijenjen pufer za demaskiranje kiselosti pH-vrijednosti 6,1 uz razrjeđenje specifičnog antitijela $1: 50$ i inkubaciju antitijelom na $+4^{\circ} \mathrm{C}$ preko noći pokazuje jako smeđe obojenje stanica i međustaničnih struktura. Pozadinsko i nespecifično bojenje jednako je signalu koji predstavlja antigen BACH2 (slika 2g).

Nakon imunohistokemijskog bojenja prereza tonzile protokolom ImmPRESS kod kojeg je primijenjen pufer za demaskiranje kiselosti $\mathrm{pH}$-vrijednosti 6,1 i razrjeđenje specifičnog antitijela $1: 100$ i inkubacija antitijelom na $+4{ }^{\circ} \mathrm{C}$ preko noći nije bilo moguće jasno odrediti signal koji predstavlja ekspresiju antigena BACH2 (slika 2h). 
Na slici 2i prikazano je imunohistokemijsko bojenje prereza protokolom ImmPRESS kod kojeg je primijenjen pufer za demaskiranje kiselosti $\mathrm{pH}$-vrijednosti 6,1, razrjeđenje antitijela $1: 50$ i vrijeme inkubacije antitijela 75 minuta. Jasno je vidljiv signal istraživanog antigena, no pozadinsko bojenje ometa precizno očitavanje rezultata.

Imunohistokemijsko bojenje prereza tonzile protokolom ImmPRESS kod kojeg je primijenjen pufer za demaskiranje kiselosti pH-vrijednosti 6,1, razrjeđenje antitijela $1: 75$ i vrijeme inkubacije antitijela 60 minuta dalo je rezultate kod kojih je jasno uočljiv signal koji predstavlja ekspresiju proteina $\mathrm{BACH} 2$ u stanicama za koje očekujemo da je njegova ekspresija prisutna, a na preparatu nema pozadinskog bojenja (slika 2j).

\section{Rasprava i zaključak}

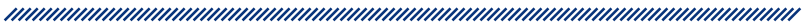

Imunohistokemijsko bojenje vrlo je složena, ali i široko primjenjiva metoda u hematopatološkim istraživanjima i rutinskoj morfološkoj analizi tkiva. Njezin je razvoj započeo 1930-ih godina, a do danas je prošla velik broj dorada. Tijekom vremena razvijale su se metode vizualizacije, što je u konačnici dovelo do uspostavljanja precizne i pouzdane metode za detekciju antigena $u$ istraživanom tkivu. Danas primjena ove metode $u$ analizi staničnih biljega koji određuju specifični fenotip pruža ključne informacije o dijagnozi i prognozi neke bolesti.

Za razliku od detekcije proteina u tekućim medijima, kod kojih su proteini izolirani iz tkiva i priređeni u velikim količinama pa ih je lako detektirati, u fiksiranim je tkivima očuvanje proteina vrlo nestabilno. Ipak, metode imunohistokemijskog bojenja tijekom godina su usavršene tako da se s visokom osjetljivošću proteini mogu odrediti u tkivima fiksiranima formalinom i uklopljenima u parafinske blokove. Kako bi metoda bila precizna i pružala rezultate koje je moguće pouzdano interpretirati, za svako je specifično antitijelo i vrstu tkiva potrebno učiniti prilagođavanje ukupnog protokola, pri čemu su najvažniji koraci demaskiranje proteina, razrjeđenje antitijela i vrijeme trajanja inkubacije tim antitijelom. Komercijalno dostupna antitijela prodaju se uz upute proizvođača za primjenu u različitim metodama, pa tako i kod imunohistokemijskog bojenja, no s obzirom na specifičnosti svakoga laboratorija, nakon odabira najpogodnijeg antitijela za pojedino tkivo i svrhu potrebno je optimizirati navedene uvjete ove metode. U slučaju antigena $\mathrm{BACH} 2$ u stanicama sekundarnog limfnog tkiva čovjeka, razvije-
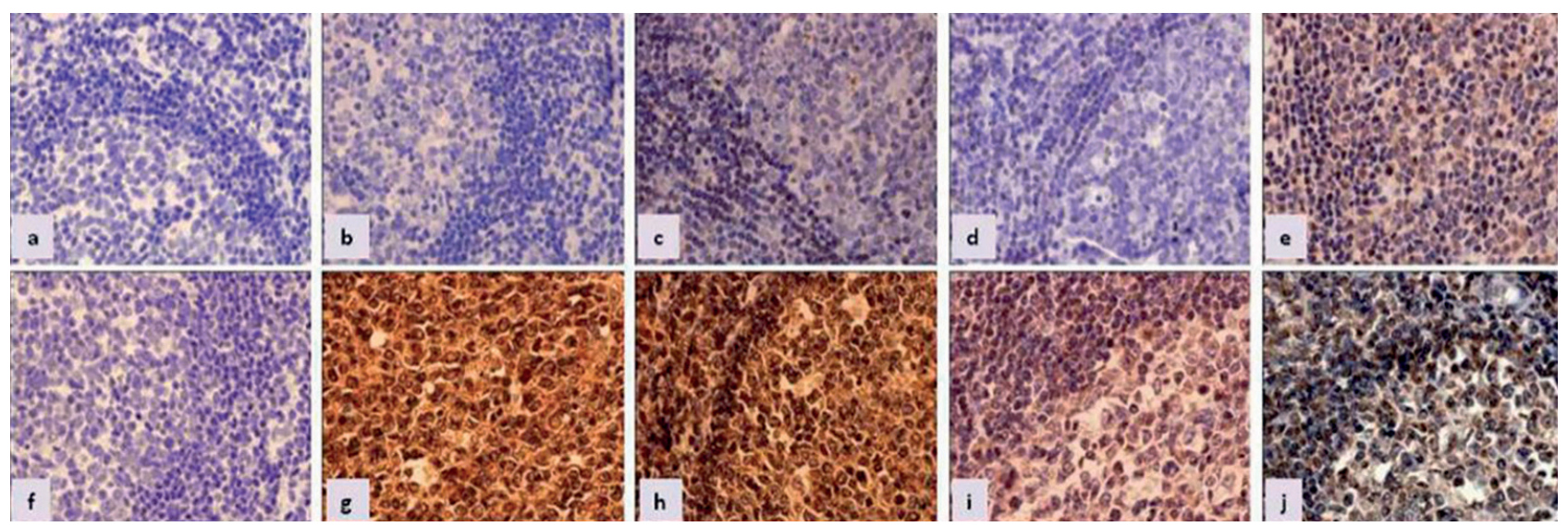

Slika 2. Imunohistokemijsko bojenje prereza tkiva tonzile (400 x) dobiveno protokolom koji uključuje: a) otkrivanje epitopa puferom $\mathrm{pH}$-vrijednosti 6,0, razrjeđenje antitijela $1: 100$ i vrijeme inkubacije

30 minuta, b) otkrivanje epitopa puferom pH-vrijednosti 6,0, razrjeđenje antitijela 1: 500 i vrijeme inkubacije 30 minuta, c) otkrivanje epitopa puferom pH-vrijednosti 6,1, razrjeđenje antitijela $1: 100 \mathrm{i}$ vrijeme inkubacije 30 minuta, d) otkrivanje epitopa puferom pH-vrijednosti 6,1, razrjeđenje antitijela $1: 500$ i vrijeme inkubacije 30 minuta, e) otkrivanje epitopa puferom pH-vrijednosti 9,0, razrjeđenje antitijela 1 : 100 i vrijeme inkubacije 30 minuta, f) otkrivanje epitopa puferom pH-vrijednosti 9,0, razrjeđenje antitijela 1: 500 i vrijeme inkubacije 30 minuta, g) otkrivanje epitopa puferom pH-vrijednosti 6,1, razrjeđenje antitijela 1 : 50 i prekonoćnu inkubaciju na $+4^{\circ} \mathrm{C}, \mathrm{h}$ ) otkrivanje epitopa puferom pH-vrijednosti 6,1, razrjeđenje antitijela 1 : 100 i prekonoćnu inkubaciju na $+4{ }^{\circ} \mathrm{C}$, i) otkrivanje epitopa puferom pH-vrijednosti 6,1, razrjeđenje antitijela $1: 50$ i vrijeme inkubacije 75 minuta, j) otkrivanje epitopa puferom pH-vrijednosti 6,1, razrjeđenje antitijela 1 : 75 i vrijeme inkubacije 60 minuta. 
no komercijalno dostupno poliklonalno antitijelo koje je napravljeno u kozi omogućava istraživanje limfoma, no potrebno je optimizirati protokol kako bi se pozadinsko bojenje smanjilo na prihvatljivi minimum $\mathrm{i}$ istovremeno detektirale čak i male količine samog proteina u stanicama koje ga proizvode.

Rezultati prikazane optimizacije metode imunohistokemijskog bojenja pokazuju da je antigen $\mathrm{BACH} 2$ navedenim antitijelom moguće najjasnije detektirati $u$ limfnom tkivu fiksiranom formalinom i uklopljenom u parafin primjenom protokola koji uključuje pufer za demaskiranje pH-vrijednosti 6,1 i razrjeđenja toga poliklonalnog antitijela u omjeru $1: 75$ uz vrijeme inkubacije antitijelom 60 minuta.

\section{Zahvala}

Hvala prof. dr. sc. Mari Dominis na pomoći oko interpretacije dobivenih rezultata i svim diskusijama koje su urodile predstavljenim protokolom.

\section{Literatura}

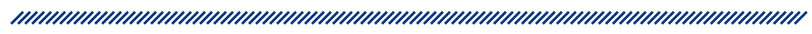

1. Coons $\mathrm{AH}$, Creech $\mathrm{HJ}$, Jones RN. Immunological Properties of an Antibody Containing a Fluorescent Group. Exp Biol Med [internet]. 1941; 47(2): 200-202. Dostupno na: http://ebm.sagepub.com/lookup/doi/10.3181/0037972747-13084P (pristupljeno 5.3.2017.).

2. O’Hurley G, Sjöstedt E, Rahman A, Li B, Kampf C, Pontén $F$, et al. Garbage in, garbage out: A critical evaluation of strategies used for validation of immunohistochemical biomarkers. Mol Oncol [internet]. 2014; 8(4): 783-798. Dostupno na: http://doi.wiley.com/10.1016/j.molonc.2014.03.008 (pristupljeno 5.3.2017.).

3. Taylor CR, Rudbeck L, ur. Immunohistochemical Staining Methods [internet]. 6. izd. Dako Denmark; 2013. 218 p. Dostupno na: http://www.agilent.com/cs/library/technicaloverviews/public/08002_ihc_staining_methods. pdf (pristupljeno 5.3.2017.).

4. Shi S-R, Liu C, Pootrakul L, Tang L, Young A, Chen R, et al. Evaluation of the Value of Frozen Tissue Section Used as „Gold Standard" for Immunohistochemistry. Am J Clin Pathol [internet]. 2008; 129(3): 358-366. Dostupno na: https://academic.oup.com/ajcp/article-lookup/ doi/10.1309/7CXUYXT23E5AL8KQ (pristupljeno 5.3.2017.).

5. Sompuram SR, Vani K, Messana E, Bogen SA. A Molecular Mechanism of Formalin Fixation and Antigen Retrieval. Am J Clin Pathol [internet]. 2004; 121(2): 190-199. Dostupno na: https://doi.org/10.1309/BRN7CTX1E84NWWPL (pristupljeno 5.3.2017.)
6. Shire SJ. Monoclonal Antibodies: Meeting the Challenges in Manufacturing, Formulation, Delivery and Stability of Final Drug Product. Cambridge, UK: Woodhead Publishing; 2015.

7. Proetzel G, Ebersbach H, ur. Methods in Molecular Biology: Antibody Methods and Protocols. Totowa, NY: Humana Press; 2012.

8. Leenaars M, Hendriksen CFM. Critical Steps in the Production of Polyclonal and Monoclonal Antibodies: Evaluation and Recommendations. ILAR J [internet]. 2005; 46(3): 269-279. Dostupno na: https://academic.oup.com/ilarjournal/article-lookup/doi/10.1093/ ilar.46.3.269 (pristupljeno 5.3.2017.).

9. Thermo Fisher Scentific Inc. IgG Fragments [brošura]. Waltham, USA: Thermo Fisher Scientific Inc.; 2007. Dostupno na: https://tools.thermofisher.com/content/sfs/brochures/ TR0059-Choose-secondary-Ab.pdf (pristupljeno 5.3.2017.).

10. Luongo de Matos L, Trufelli DC, Luongo de Matos MG, da Silva Pinhal MA. Immunohistochemistry as an Important Tool in Biomarkers Detection and Clinical Practice. Biomark Insights [internet]. 2010; 5: 9-20. Dostupno na: https:// www.ncbi.nlm.nih.gov/pmc/articles/PMC2832341/pdf/ bmi-2010-009.pdf (pristupljeno 5.3.2017.).

11. Van der Loos C. Nuance Imaging Systems. User Protocol: Practical Guide to Multiple Staining. Cambridge Research \& Instrumentation, Inc. Dostupno na: http://www. biotechniques.com/multimedia/archive/00074/CRI-FPMicroscopy_74545a.pdf (pristupljeno 5.3.2017.).

12. Burry RW. Immunocytochemistry: A Pratical Guide for Biomedical Research. New York: Springer-Verlag New York, Inc.; 2010.

13. Pástor MVD. Direct Immunofluorescent Labeling of Cells. U: Oliver C, Jamur MC, ur. Immunocythochemical Methods and Protocol. Humana Press; 2010. 135-142. Dostupno na: http://link.springer.com/10.1007/978-1-59745324-0_16 (pristupljeno 5.3.2017.).

14. Liu, H. Breast. U: Lin F, Prichard J, ur. Handbook of Practical Immunohistochemistry [internet]. New York: Springer; 2011. 115-116. Dostupno na: http://www.springer. com/gp/book/9781493915774 (pristupljeno 5.3.2017.).

15. Bratthauer GL. The Peroxidase-Antiperoxidase (PAP) Method. U: Javois LC, ur. Immunocytochemical Methods and Protocols [internet]. Totowa, NJ: Humana Press; 1995. 165-173. Dostupno na: http://link.springer. com/10.1385/0-89603285-X:165 (pristupljeno 5.3.2017.).

16. Hsu SM, Raine L, Fanger H. Use of avidin-biotin-peroxidase complex $(A B C)$ in immunoperoxidase techniques: a comparison between $\mathrm{ABC}$ and unlabeled antibody (PAP) procedures. J Histochem Cytochem [internet]. 1981; 29(4): 577-580. Dostupno na: http://www.ncbi.nlm.nih. gov/pubmed/6166661 (pristupljeno 5.3.2017.).

17. Bratthauer GL. Overview of Antigen Detection Through Enzymatic Activity. Methods Mol Biol [internet]. 2010; 588: 231-241. Dostupno na: http://www.ncbi.nlm.nih. gov/pubmed/20012835 (pristupljeno 5.3.2017.).

18. Vyberg M, Nielsen S. Dextran Polymer Conjugate TwoStep Visualization System for Immunohistochemistry: A Comparison of EnVision+ With Two Three-Step Avidin- 
Biotin Techniques. Appl Immunohistochem [internet]. 1999; 6(1): 3-10. Dostupno na: http://insights.ovid.com/ applied-immunohistochemistry/aimmc/1998/03/000/ dextran-polymer-conjugate-two-step-visualization/2/01212984 (pristupljeno 5.3.2017.).

19. Ramos-Vara JA, Miller MA. Comparison of two polymerbased immunohistochemical detection systems: ENVISION+ and ImmPRESS. J Microsc [internet]. 2006; 224(2): 135-139. Dostupno na: http://doi.wiley.com/10.1111/ j.1365-2818.2006.01679.x (pristupljeno 5.3.2017.).

20. Kim EH, Gasper DJ, Lee SH, Plisch EH, Svaren J, Suresh $\mathrm{M}$. Bach2 regulates homeostasis of Foxp3+ regulatory $T$ cells and protects against fatal lung disease in mice. $J$ Immunol [internet]. 2014; 192(3): 985-995. Dostupno na: http://www.jimmunol.org/content/192/3/985.full (pristupljeno 5.3.2017.).

21. Cuturi MC, Anegon I, ur. Suppression and Regulation of Immune Responses: Methods and Protocols. Totowa: Humana Press; 2011.

22. Igarashi K, Ochiai K, Itoh-Nakadai A, Muto A. Orchestration of plasma cell differentiation by Bach2 and its gene regulatory network. Immunol Rev [internet]. 2014; 261(1): 116-125. Dostupno na: http://www.ncbi.nlm.nih. gov/pubmed/25123280 (pristupljeno 10.11.2015.).

23. Nakane PK, Pierce GB. Enzyme-labeled antibodies: Preparation and application for the localization of antigens. J Histochem Cytochem [internet]. 1966; 14(12): 929-931. Dostupno na: http://journals.sagepub.com/ doi/10.1177/14.12.929 (pristupljeno 26.2.2017.).

24. Sternberger LA, Hardy PH, Cuculis JJ, Meyer HG. The unlabeled antibody enzyme method of immunohistochemistry preparation and properties of soluble antigen-antibody complex (Horseradish peroxidase-antihorseradish peroxidase) and its use in identification of spirochetes. J Histochem Cytochem [internet]. 1970; 18(5): 315-333. Dostupno na: http://jhc.sagepub.com/ lookup/doi/10.1177/18.5.315 (pristupljeno 22.3.2017.).

25. Kawarai Y, Nakane PK. Localization of tissue antigens on the ultrathin sections with peroxidase-labeled antibody method. J Histochem Cytochem [internet]. 1970; 18(3): 161-166. Dostupno na: http://journals.sagepub.com/ doi/10.1177/18.3.161 (pristupljeno 22.3.2017.).

26. Taylor $\mathrm{C}$. The nature of Reed-Sternberg cells and other malignant „Reticulum” cells. The Lancet [internet]. 1974; 304(7884): 802-807. Dostupno na: http://linkinghub.elsevier.com/retrieve/pii/S014067367491071X (pristupljeno 22.3.2017.).

27. Taylor CR, Burns J. The demonstration of plasma cells and other immunoglobulin- containing cells in formalin-fixed, paraffin-embedded tissues using peroxidaselabelled antibody. J Clin Pathol [internet]. 1974; 27(1): 14-20. Dostupno na: http://www.ncbi.nlm.nih.gov/ pubmed/4132252 (pristupljeno 22.3.2017.).

28. Taylor CR, Mason DY. The immunohistological detection of intracellular immunoglobulin in formalin-paraffin sections from multiple myeloma and related conditions using the immunoperoxidase technique. Clin Exp Immunol [inter- net]. 1974; 18(3): 417-429. Dostupno na: http://www.ncbi. nlm.nih.gov/pubmed/4219910 (pristupljeno 22.3.2017.).

29. Köhler G, Milstein C. Continuous cultures of fused cells secreting antibody of predefined specificity. Nature [internet]. 1975; 256(5517): 495-497. Dostupno na: http://www.nature. com/doifinder/10.1038/256495a0 (pristupljeno 22.3.2017.).

30. Mason DY, Sammons R. Alkaline phosphatase and peroxidase for double immunoenzymatic labelling of cellular constituents. J Clin Pathol [internet]. 1978; 31(5): 454-460. Dostupno na: http://www.ncbi.nlm.nih.gov/ pubmed/77279 (pristupljeno 22.3.2017.).

31. McMichael AJ, Pilch JR, Fabre JW, Mason DY, Galfré G, Milstein $C$. A human thymocyte antigen defined by a hybrid myeloma monoclonal antibody. Eur J Immunol [internet]. 1979; 9(3): 205-210. Dostupno na: http://doi.wiley. com/10.1002/eji.1830090307 (pristupljeno 22.3.2017.).

32. Brigati DJ, Budgeon LR, Unger ER, Koebler D, Cuomo C, Kennedy T, et al. Immunocytochemistry is Automated: Development of A Robotic Workstation Based Upon the Capillary Action Principle. J Histotechnol [internet]. 1988; 11(3): 165-183. Dostupno na: http://www.tandfonline.com/doi/ full/10.1179/his.1988.11.3.165 (pristupljeno 22.3.2017.).

33. Shi SR, Key ME, Kalra KL. Antigen retrieval in formalinfixed, paraffin-embedded tissues: an enhancement method for immunohistochemical staining based on microwave oven heating of tissue sections. J Histochem Cytochem [internet]. 1991; 39(6): 741-748. Dostupno na: http://journals.sagepub.com/doi/10.1177/39.6.1709656 (pristupljeno 22.3.2017.).

34. Taylor CR. An exaltation of experts: Concerted efforts in the standardization of immunohistochemistry. Hum Pathol [internet]. 1994; 25(1): 2-11. Dostupno na: http:// linkinghub.elsevier.com/retrieve/pii/0046817794901643 (pristupljeno 22.3.2017.).

35. Goldstein NS, Hewitt SM, Taylor CR, Yaziji H, Hicks DG. Recommendations for Improved Standardization of Immunohistochemistry. Appl Immunohistochem Mol Morphol [internet]. 2007; 15(2): 124-133. Dostupno na: http://content.wkhealth.com/linkback/openurl?sid=WK PTLP:landingpage\&an=00129039-200706000-00002 (pristupljeno 22.3.2017.).

36. Wolff AC, Hammond ME, Schwartz JN, Hagerty KL, Allred DC, Cote RJ, et al. American Society of Clinical Oncology/ College of American Pathologists guideline recommendations for human epidermal growth factor receptor 2 testing in breast cancer. Arch Pathol Lab Med [internet]. 2007; 131(1): 18-43. Dostupno na: http://www.ncbi.nlm. nih.gov/pubmed/19548375 (pristupljeno 22.3.2017.).

37. Allison M. The HER2 testing conundrum. Nat Biotechnol [internet]. 2010; 28(2): 117-119. Dostupno na: http:// www.nature.com/doifinder/10.1038/nbt0210-117 (pristupljeno 22.3.2017.). 


\section{DEVELOPMENT OF IMMUNOHISTOCHEMICAL STAINING METHODS AND OPTIMIZATION OF IMMUNOHISTOCHEMICAL PROTOCOL FOR BACH2 TRANSCRIPTION FACTOR}

1 Nikolina Vukoja

2 Suzana Hančić

3 Petra Korać

1 Department of Clinical Laboratory Diagnostics, Children's Hospital Srebrnjak, Srebrnjak 100, Zagreb, Croatia

2 Department of Pathology and Cytology, University Hospital Merkur, Zajčeva 19, Zagreb, Croatia

3 Division of Molecular Biology, Department of Biology, Faculty of Science of the University of Zagreb, Horvatovac 102a, Zagreb, Croatia

\section{Abstract}

Immunohistochemical staining is a method for detection of presence and localization of specific antigens in cells and/or tissues. It is based on the basic principle of immunoreactions: binding of specific antibody to a certain antigen. Development of immunohistochemical staining methods started during the 1930s and, in a number of variations, they are still used today both in research and routine diagnostic procedures.

This paper offers presentation of immunohistochemical methods development and gives an example of protocol optimization for detection of $\mathrm{BACH} 2$ antigen in human secondary lymphoid tissue. Most important steps of the protocol are discussed (section preparation, antigen demasking and specific antibody incubation conditions). Optimal protocol for immunohistochemical staining for $\mathrm{BACH} 2$ antigen is given and can be used in any routine hematopathological laboratory.

Keywords: immunohistochemical staining, $\mathrm{BACH} 2$, epitope demasking, antibody incubation 